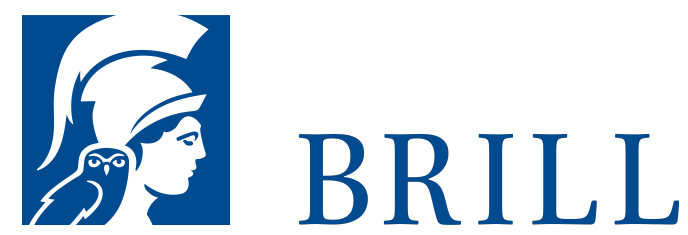

\title{
Liberaler Verfassungsstaat und gutes Leben
}

Über verfassungsrechtliche Grenzen ethisch imprägnierter Gesetzgebung

Author: Martin Nettesheim

In der Ordnung des Grundgesetzes wird die Frage danach, welche Behandlung die unterschiedlichen Konzeptionen des guten Lebens erfahren sollen, im Zuge weiterer Pluralisierung der Lebensvorstellungen an Bedeutung gewinnen. Bislang hat sich die Verfassungstheorie mit dieser Frage in grundsätzlicher Hinsicht zu wenig befasst. Stattdessen werden Konflikte durch Einzelfallabwägung bewältigt. Die Studie versucht, Demokratie und Grundrechtsschutz in prinzipieller Weise zusammenzuführen. Sie zeigt einerseits auf, dass der Gesetzgeber grundsätzlich darin frei ist, bestimmte Vorstellungen darüber, wie ein gutes Leben zu führen ist, $\mathrm{zu}$ privilegieren. Er verstößt damit weder gegen theoretische Prämissen verfassungsstaatlicher Herrschaft noch positivrechtliche Grundsätze des geltenden Verfassungsrechts. Der Staat des Grundgesetzes ist als demokratischer Staat gerade kein ethisch neutraler Staat. Sie weist andererseits darauf hin, dass sich die grundrechtlichen Grenzen gesetzgeberischer Entscheidungen zugunsten oder gegen eine bestimmte Konzeption des guten Lebens nicht allein auf der Basis eines liberalen Begriffs der Personen bestimmen lassen. Die »Grundrechtsperson« ist zugleich Träger gleicher Freiheit, verfügt über eine ethische Identität und kann politische Autonomie beanspruchen. Nur wenn die Grundrechtskontexte zu einem gehaltvollen Konzept zusammengeführt werden, lässt...

See More

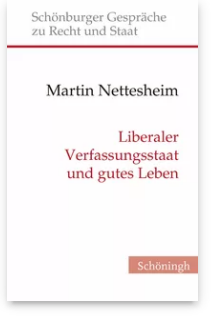

Pages: 111 Seiten Language:

German

Subjects:

Economics \&

Political Science,

Social Sciences

Publisher: Brill |

Schöningh

Series:

Schönburger

Gespräche zu

Recht und Staat,

Volume: 28

E-Book (PDF)

Released online:

23 Oct 2017

ISBN: $978-3^{-}$

657-78849-1

List price

Hardback

Publication date: o8 Sep 2017

ISBN: 978-3506-78849-8 List price 
Biographical Note

Martin Nettesheim ist Universitätsprofessor an der Universität Tübingen und Inhaber des Lehrstuhls für Staatsund Verwaltungsrecht, Europarecht und Völkerrecht.

For more information see brill.com

Order information: Order online at brill.com +44 330 333 0049 | customerservices@brill.com Submission information: brill.com/authors

Titles published by Brill | Fink, Brill | mentis or Brill | Schöningh: +49(o)71 5413279216 | brill@brocom.de 